\title{
High levels of vegetable oils in plant protein-rich diets fed to gilthead sea bream (Sparus aurata L.): growth performance, muscle fatty acid profiles and histological alterations of target tissues
}

\author{
Laura Benedito-Palos $^{1}$, Juan C. Navarro ${ }^{1}$, Ariadna Sitjà-Bobadilla ${ }^{1}$, J. Gordon Bell $^{2}$, Sadasivam Kaushik ${ }^{3}$ \\ and Jaume Pérez-Sánchez ${ }^{1 *}$ \\ ${ }^{1}$ Department of Biology, Culture and Pathology of Marine Species, Institute of Aquaculture Torre de la Sal (CSIC), \\ 12595 Ribera de Cabanes, Castellón, Spain \\ ${ }^{2}$ Institute of Aquaculture, University of Stirling, Stirling FK9 4LA, UK \\ ${ }^{3}$ UMR Nutrition, Aquaculture and Genomics, INRA, Unité-Mixte INRA-IFREMER-Université Bordeaux I, 64310 \\ Saint-Pée-sur-Nivelle, France \\ (Received 1 October 2007 - Revised 31 January 2008 - Accepted 6 February 2008 - First published online 1 April 2008)
}

\begin{abstract}
The feasibility of fish oil (FO) replacement by vegetable oils (VO) was investigated in gilthead sea bream (Sparus aurata L.) in a growth trial conducted for the duration of 8 months. Four isolipidic and isoproteic diets rich in plant proteins were supplemented with L-lysine $(0.55 \%)$ and soya lecithin (1\%). Added oil was either FO (control) or a blend of VO, replacing 33\% (33VO diet), 66\% (66VO diet) and 100\% (VO diet) of FO. No detrimental effects on growth performance were found with the partial FO replacement, but feed intake and growth rates were reduced by about $10 \%$ in fish fed the VO diet. The replacement strategy did not damage the intestinal epithelium, and massive accumulation of lipid droplets was not found within enterocytes. All fish showed fatty livers, but signs of lipoid liver disease were only found in fish fed the VO diet. Muscle fatty acid profiles of total lipids reflected the diet composition with a selective incorporation of unsaturated fatty acids in polar lipids. The robustness of the phospholipid fatty acid profile when essential fatty acid requirements were theoretically covered by the diet was evidenced by multivariate principal components analysis in fish fed control, $33 \mathrm{VO}$ and $66 \mathrm{VO}$ diets.
\end{abstract}

Essential fatty acids: Phospholipids: Soya lecithin: Lipoid liver disease

Marine fish farming is mostly based on diets containing high levels of $n$-3 highly unsaturated fatty acids (HUFA), particularly EPA $(20: 5 n-3)$ and DHA $(22: 6 n-3)$. However, the continuous expansion of aquaculture and the decreasing global availability of marine oil and fishmeal force the industry to explore alternative and sustainable lipid sources ${ }^{(1,2)}$. In salmonids, the use of vegetable oils to replace the majority of dietary fish oil (FO) is now feasible in practical aquafeeds without loss of growth performance ${ }^{(3-5)}$. Nevertheless, essential fatty acid (EFA) requirements differ between species. Thus, linoleic acid $(18: 2 n-6)$ and $\alpha$-linolenic acid $(18: 3 n-3)$ can satisfy the EFA requirements of freshwater fish, whereas marine fish require longer-chain $n-3$ and $n-6$ PUFA for optimal growth and health ${ }^{(6)}$. Supporting this, fatty acid desaturation and elongation of linoleic acid and $\alpha$-linolenic acid are well established in freshwater and anadromous fish species ${ }^{(7)}$, but marine fish including European sea bass ${ }^{(8)}$ and gilthead sea bream (Sparus aurata L.) ${ }^{(9,10)}$ do not show rates for bioconversion of $C_{18}$ PUFA into $C_{20}$ and $\mathrm{C}_{22}$ HUFA that would allow $n-3$ HUFA requirements to be met.

Signs of EFA deficiencies in fish include skin lesions and several neurological alterations linked to reduced growth and survival rates during larval and juvenile on-growing phases $^{(11)}$. Lipoid liver disease and intense accumulation of intestinal lipid droplets are also documented as metabolic disorders arising from defective supplies of phospholipids (PL) ${ }^{(12-14)}$ and $n-3$ HUFA $^{(15)}$. Additionally, fatty acids modulate immune responses and eicosanoids produced from arachidonic acid $(20: 4 n-6)$ are recognised as inflammatory agents, whereas DHA, and especially EPA-derived eicosanoids, exert anti-inflammatory effects in a wide variety of experimental models ${ }^{(16,17)}$. However, factors other than dietary ones may influence lipid metabolism, and relative rates of fat deposition and mobilisation vary greatly as a result of environmental factors including parr-smolt transformation in salmonids ${ }^{(18,19)}$. Likewise, gonadal maturation and spawning have a significant impact in the muscle fatty acid profile

Abbreviations: EFA, essential fatty acid; FO, fish oil; HUFA, highly unsaturated fatty acid; MPCA, multivariate principal components analysis; PL, phospholipid; TL, total lipids; VO diet, diet in which vegetable oil replaces $100 \%$ of fish oil; 33VO diet, diet in which vegetable oil replaces $33 \%$ of fish oil; $66 \mathrm{VO}$ diet, diet in which vegetable oil replaces $66 \%$ of fish oil.

* Corresponding author: Dr Jaume Pérez-Sánchez, fax +34 964319509, email jperez@iats.csic.es 
of gilthead sea bream females ${ }^{(20)}$. Deposition rates and fatty acid profiles also vary seasonally in wild gilthead sea bream $^{(21)}$, but the feeding regimen is a major influence and most of these changes can be overridden by full rations given under intensive aquaculture. Indeed, monitoring studies in various Greek fish farms failed to show a seasonal impact in the muscle fat deposition and profiling of gilthead sea bream ${ }^{(22)}$.

Gilthead sea bream is a major cultured finfish in the Mediterranean area, and extensive research to sustain further growth has proved that vegetable oils can replace up to $60 \%$ of the added FO, in fishmeal-based diets, without adverse effects on growth, feed efficiency and survival rates ${ }^{(8,23,24)}$. Additional studies have addressed the extensive replacement of fishmeal by plant proteins ${ }^{(25,26)}$, and recently growth-compensatory mechanisms of the somatotropic axis have been evidenced in short-term trials when juvenile fish were fed during the summer growth spurt with plant proteinbased diets and graded levels of vegetable oils ${ }^{(27)}$. Indeed, with the total replacement of dietary FO some growth reduction occurred, and it was accompanied by decreased production of hepatic insulin-like growth factor-I not compensated by the local expression (skeletal muscle) of insulin-like growth factor and/or growth hormone receptors. In humans and other animal models, there is also increasing evidence linking endocrine and metabolic dysfunctions resulting in obesity and insulin resistance with steatosic livers and altered fatty acid profiles of PL and stored $\mathrm{TAG}^{(28)}$. In this sense, three major goals were addressed in the present paper in a gilthead sea bream trial conducted over a growth trial of 8 months' duration: (a) the relationship between dietary and muscle fatty acid profiles; (b) the robustness of the PL fatty acid profile when EFA requirements are theoretically covered in the diet; (c) histological alterations of liver and intestine as sensitive target tissues of lipid-metabolism dysregulation.

\section{Materials and methods}

Diets

Four isoproteic, isolipidic and isoenergetic plant proteinbased diets were made with a low inclusion level (20\%) of fishmeal and fish soluble protein concentrates (Tables 1 and 2). All diets were supplemented with L-lysine (0.55\%) and contained soya lecithin $(1 \%)$. Added oil was either Scandinavian FO (control diet) or a blend of vegetable oils, replacing $33 \%$ (33VO diet), $66 \%$ (66VO diet) and $100 \%$ (VO diet) of the FO. The blend of vegetable oils (rapeseed oil-linseed oil-palm oil, 2·5:28.8:3·6, by wt) provided a similar balance of saturates, monoenes and PUFA to that found in FO, but without HUFA ${ }^{(29,30)}$. All diets were manufactured using a twin-screw extruder (Clextral, BC $45)$ at the INRA experimental research station of Donzacq (Landes, France), dried under hot air, sealed and kept in air-tight bags until use.

\section{Growth trial and tissue sampling}

Juvenile gilthead sea bream of Atlantic origin (Ferme Marine de Douhet, Ile d'Oléron, France) were acclimatised to laboratory conditions at the Institute of Aquaculture Torre de la Sal (IATS) for $20 \mathrm{~d}$ before the start of the growth study. Fish of
Table 1. Ingredients and chemical composition of experimental diets

\begin{tabular}{|c|c|c|c|c|}
\hline & \multicolumn{4}{|c|}{ Diet } \\
\hline & Control & $33 \mathrm{VO}$ & $66 \mathrm{VO}$ & VO \\
\hline \multicolumn{5}{|l|}{ Ingredient (\%) } \\
\hline Fishmeal (CP $70 \%)^{*}$ & $15 \cdot 00$ & $15 \cdot 00$ & $15 \cdot 00$ & $15 \cdot 00$ \\
\hline CPSP 90† & $5 \cdot 00$ & $5 \cdot 00$ & $5 \cdot 00$ & 5.00 \\
\hline Maize gluten meal (CP 63\%) & $40 \cdot 00$ & $40 \cdot 00$ & $40 \cdot 00$ & $40 \cdot 00$ \\
\hline Soyabean meal (CP $46 \%)$ & $14 \cdot 30$ & $14 \cdot 30$ & $14 \cdot 30$ & $14 \cdot 30$ \\
\hline Extruded wheat (CP 15\%) & 4.00 & 4.00 & 4.00 & $4 \cdot 00$ \\
\hline Fish oilł & $15 \cdot 15$ & $10 \cdot 15$ & $5 \cdot 15$ & 0.00 \\
\hline Rapeseed oil & 0.00 & 0.85 & $1 \cdot 70$ & $2 \cdot 58$ \\
\hline Linseed oil & 0.00 & $2 \cdot 90$ & $5 \cdot 80$ & $8 \cdot 79$ \\
\hline Palm oil & 0.00 & $1 \cdot 25$ & $2 \cdot 50$ & 3.79 \\
\hline Soya lecithin & 1.00 & 1.00 & $1 \cdot 00$ & 1.00 \\
\hline Binder (sodium alginate) & 1.00 & 1.00 & 1.00 & 1.00 \\
\hline Mineral premix§ & 1.00 & 1.00 & 1.00 & $1 \cdot 00$ \\
\hline Vitamin premix\| & 1.00 & 1.00 & 1.00 & 1.00 \\
\hline $\mathrm{CaHPO}_{4} \cdot 2 \mathrm{H}_{2} \mathrm{O}(18 \% \mathrm{P})$ & $2 \cdot 00$ & $2 \cdot 00$ & $2 \cdot 00$ & $2 \cdot 00$ \\
\hline L-Lysine & 0.55 & 0.55 & 0.55 & 0.55 \\
\hline \multicolumn{5}{|l|}{ Proximate composition } \\
\hline DM (\%) & 93.43 & $94 \cdot 10$ & 94.79 & $95 \cdot 38$ \\
\hline Protein (\% DM) & $48 \cdot 98$ & $48 \cdot 74$ & $49 \cdot 03$ & $48 \cdot 65$ \\
\hline Fat (\% DM) & $22 \cdot 19$ & $22 \cdot 26$ & $22 \cdot 11$ & $22 \cdot 31$ \\
\hline Ash (\% DM) & $6 \cdot 54$ & 6.57 & $6 \cdot 62$ & $6 \cdot 41$ \\
\hline $\mathrm{EPA}+\mathrm{DHA}(\% \mathrm{DM})$ & $2 \cdot 31$ & 1.61 & 0.90 & 0.30 \\
\hline Gross energy (kJ/g DM) & $24 \cdot 72$ & $24 \cdot 71$ & $24 \cdot 65$ & 24.49 \\
\hline
\end{tabular}

$33 \mathrm{VO}$ diet, diet in which vegetable oil replaces $33 \%$ of fish oil; $66 \mathrm{VO}$, diet in which vegetable oil replaces $66 \%$ of fish oil; VO diet, diet in which vegetable oil replaces $100 \%$ of fish oil; CP, crude protein.

${ }^{*}$ Fishmeal (Scandinavian LT; Norsildmel, Fyllingsdalen, Norway).

† Fish soluble protein concentrate (Sopropêche, Boulogne-Sur-Mer, France). ¥3 Fish oil (Sopropêche).

$\S$ Supplied the following $(\mathrm{mg} / \mathrm{kg}$ diet, except as noted): calcium carbonate $(40 \%$ Ca), $2.15 \mathrm{~g}$; magnesium hydroxide $(60 \% \mathrm{Mg}), 1.24 \mathrm{~g}$; potassium chloride, $0.9 \mathrm{~g}$; ferric citrate, $0.2 \mathrm{~g}$; potassium iodide, 4 ; sodium chloride, $0.4 \mathrm{~g}$; calcium hydrogen phosphate, $50 \mathrm{~g}$; copper sulfate, 0.3 ; zinc sulfate, 40 ; cobalt sulfate, 2 ; manganese sulfate, 30 ; sodium selenite, 0.3 .

II Supplied the following ( $\mathrm{mg} / \mathrm{kg}$ diet): retinyl acetate, 2.58; DL-cholecalciferol, 0.037; $\mathrm{DL}-\alpha$-tocopheryl acetate, 30; menadione sodium bisulfite, 2.5; thiamin, 7.5; riboflavin, 15; pyridoxine, 7.5; nicotinic acid, 87.5 ; folic acid, 2.5; calcium pantothenate, 2.5; vitamin $\mathrm{B}_{12}, 0.025$; ascorbic acid, 250; inositol, 500; biotin 1.25; choline chloride, 500 .

$16 \mathrm{~g}$ initial mean body weight were distributed into twelve fibreglass tanks (500 litres) in groups of sixty fish per tank. Water flow was 20 litres/min, and $\mathrm{O}_{2}$ content of outlet water remained higher than $85 \%$ saturation. The growth study was undertaken over 8 months (23 May to 18 January), and daylength and water temperature $\left(11-27^{\circ} \mathrm{C}\right)$ varied over the course of the trial following natural changes at IATS latitude $\left(40^{\circ} 5^{\prime} \mathrm{N} ; 0^{\circ} 10^{\prime} \mathrm{E}\right)$.

Each diet was randomly allocated to triplicate groups of fish, and feed was offered by hand to apparent visual satiety twice per day (09.00 and 14.00 hours) from May to September, and once per day (12.00 hours) from October to January. No mortality was registered, and feed intake was recorded daily. At regular intervals, fish were counted and groupweighed under moderate anaesthesia (3-aminobenzoic acid ethyl ester, MS 222;100 $\mu \mathrm{g} / \mathrm{ml})$. At critical step windows over the growth trial (midsummer, 5 August; early autumn, 27 September; early winter, 18 January), randomly selected fish (four fish per tank; twelve fish per treatment) were killed by a blow on the head before tissue sampling. Portions of dorsal muscle (white muscle) were extracted and rapidly excised, frozen in liquid $\mathrm{N}_{2}$, and stored at $-80^{\circ} \mathrm{C}$ until fatty acid analyses of lipid extracts. Liver and intestine samples 
Table 2. Fatty acid composition of experimental diets (\% of total fatty acid methyl esters)

(Mean values of two determinations)

\begin{tabular}{|c|c|c|c|c|}
\hline \multirow[b]{2}{*}{ Fatty acids } & \multicolumn{4}{|c|}{ Diet } \\
\hline & Control & $33 \mathrm{VO}$ & $66 \mathrm{VO}$ & VO \\
\hline $14: 0$ & 5.02 & $3 \cdot 70$ & 1.89 & 0.59 \\
\hline $15: 0$ & 0.35 & 0.22 & 0.13 & 0.12 \\
\hline $16: 0$ & $16 \cdot 70$ & $16 \cdot 90$ & $16 \cdot 9$ & $16 \cdot 7$ \\
\hline $16: 1 n-7$ & 4.63 & 2.97 & 1.96 & 0.76 \\
\hline $16: 1 n-9$ & 0.22 & 0.15 & $\operatorname{tr}$ & $\operatorname{tr}$ \\
\hline $16: 2$ & 0.49 & 0.35 & 0.26 & 0.14 \\
\hline $16: 3 n-3$ & 0.19 & 0.13 & 0.08 & $\operatorname{tr}$ \\
\hline $16: 4$ & 0.40 & 0.29 & 0.17 & $\operatorname{tr}$ \\
\hline $17: 0$ & 0.41 & 0.29 & 0.23 & $0 \cdot 10$ \\
\hline $18: 0$ & 2.55 & 2.92 & 3.43 & 3.73 \\
\hline $18: 1 n-9$ & 12.50 & 17.50 & 21.90 & 25.90 \\
\hline $18: 1 n-7$ & 1.92 & 1.69 & 1.49 & 1.21 \\
\hline $18: 2 n-6$ & $12 \cdot 10$ & $15 \cdot 70$ & $19 \cdot 20$ & $21 \cdot 30$ \\
\hline $18: 3 n-3$ & 1.58 & 8.94 & $16 \cdot 30$ & $23 \cdot 20$ \\
\hline $18: 4 n-3$ & $2 \cdot 16$ & 1.47 & 0.82 & 0.20 \\
\hline $20: 0$ & 0.30 & 0.30 & 0.31 & 0.29 \\
\hline $20: 1 n-9$ & $7 \cdot 24$ & $5 \cdot 12$ & 3.05 & 1.06 \\
\hline $20: 1 n-7$ & 0.21 & $0 \cdot 16$ & 0.09 & $\operatorname{tr}$ \\
\hline $20: 2 n-6$ & 0.17 & 0.12 & 0.11 & $\operatorname{tr}$ \\
\hline $20: 3 n-3$ & 0.08 & 0.07 & $\operatorname{tr}$ & $\operatorname{tr}$ \\
\hline $20: 4 n-6$ & 0.31 & 0.22 & 0.13 & $\operatorname{tr}$ \\
\hline $20: 4 n-3$ & 0.43 & 0.28 & 0.15 & $\operatorname{tr}$ \\
\hline $20: 5 n-3$ & 6.86 & 4.68 & 2.75 & 0.94 \\
\hline $22: 0$ & $\operatorname{tr}$ & 0.16 & 0.16 & 0.17 \\
\hline $22: 1 n-11$ & $10 \cdot 19$ & 6.74 & 3.68 & 0.74 \\
\hline $22: 1 n-9$ & 0.56 & 0.43 & 0.29 & 0.16 \\
\hline $22: 5 n-3$ & 0.64 & 0.40 & 0.18 & $\operatorname{tr}$ \\
\hline $22: 6 n-3$ & 8.34 & $5 \cdot 68$ & 3.38 & 1.06 \\
\hline Total & 96.55 & 97.58 & 98.04 & 98.37 \\
\hline Saturates & $25 \cdot 33$ & 24.33 & 22.89 & 21.53 \\
\hline Monoenes & 37.47 & 34.76 & 32.46 & 29.83 \\
\hline$n-3$ HUFA $^{*}$ & $16 \cdot 35$ & $11 \cdot 11$ & 6.46 & 2.00 \\
\hline$n-6$ HUFA $\dagger$ & 0.48 & 0.34 & 0.24 & $\operatorname{tr}$ \\
\hline
\end{tabular}

$33 \mathrm{VO}$ diet, diet in which vegetable oil replaces $33 \%$ of fish oil; $66 \mathrm{VO}$, diet in which vegetable oil replaces $66 \%$ of fish oil; VO diet, diet in which vegetable oil replaces $100 \%$ of fish oil; tr, trace values $<0.05$; HUFA, highly unsaturated fatty acids.

* Calculated excluding $18 \mathrm{C}$ atoms of the $n-3$ series.

† Calculated excluding $18 \mathrm{C}$ atoms of the $n-6$ series.

for fat content determinations and histological samples were taken only in September ( $20 \mathrm{~h}$ after the last feeding) when fish still show an active feeding behaviour. All procedures were carried out according to national and institutional regulations (Consejo Superior de Investigaciones Científicas, Institute of Aquaculture Torre de la Sal Review Board) and the current European Union legislation on handling experimental animals.

\section{Histology and tissue lipid content determinations}

Tissue fragments of liver and hindgut were fixed in $10 \%$ buffered formalin, embedded in Technovit-7100 resin (Kulzer, Heraeus, Germany), and stained with toluidine blue or haematoxylin-eosin after thin sectioning $(1-3 \mu \mathrm{m})$. Liver and muscle lipids were extracted according to Folch et al. ${ }^{(31)}$, and determined gravimetrically after the evaporation of the organic solvent under a stream of $\mathrm{N}_{2}$ and overnight desiccation.

\section{Fatty acid analyses}

Muscle total lipids (TL) for fatty acid analyses were extracted by the method of Folch et al. ${ }^{(31)}$, using chloroform-methanol $(2: 1, \mathrm{v} / \mathrm{v})$ containing $0.01 \%$ butylated hydroxytoluene as antioxidant. PL from muscle lipid extracts were isolated by TLC (Silica gel G 60, $20 \times 20 \mathrm{~cm}$ glass plates; Merck, Darmstadt, Germany) using hexane-diethyl ether-acetic acid (85:15:1.5, by vol.) as a solvent system. PL bands at the bottom of plates were scraped and extracted with chloroform-methanol $(2: 1, \mathrm{v} / \mathrm{v})$ containing $0.01 \%$ butylated hydroxytoluene.

After the addition of nonadecaenoic acid (Sigma, Poole, Dorset, UK) as internal standard, muscle PL and TL extracts were subjected to acid-catalysed transmethylation for $16 \mathrm{~h}$ at $50^{\circ} \mathrm{C}$ using $1 \mathrm{ml}$ toluene and $2 \mathrm{ml} 1 \%(\mathrm{v} / \mathrm{v})$ sulfuric acid in methanol ${ }^{(32)}$. Fatty acid methyl esters were extracted with hexane-diethyl ether $(1: 1, \mathrm{v} / \mathrm{v})$, and those derived from TL were purified by TLC using hexane-diethyl ether-acetic acid (85:15:1.5, by vol.) as a solvent system. Fatty acid methyl esters were then analysed with a gas chromatograph (Fisons Instruments GC 8000 Series; Rodano, Italy) equipped with a fused silica $30 \mathrm{~m} \times 0.25 \mathrm{~mm}$ open tubular column (Tracer, TR-WAX; film thickness: $0.25 \mu \mathrm{m}$; Teknokroma, Spain) and a cold on-column injection system. The carrier gas used was $\mathrm{He}$, and temperature programming was from 50 to $180^{\circ} \mathrm{C}$ at $40^{\circ} \mathrm{C} / \mathrm{min}$ and then to $220^{\circ} \mathrm{C}$ at $3^{\circ} \mathrm{C} / \mathrm{min}$. Peaks were recorded in a personal computer using the Azur software package (version 4.0.2.0; Datalys, Saint-Martind'Hères, France). Individual fatty acid methyl esters were identified by reference to well-characterised FO standards, and the relative amount of each fatty acid was expressed as a percentage of the total amount of fatty acids in the analysed sample.

\section{Statistical analysis}

Growth parameters (tank average values) and the relative amount of fatty acids were checked for normal distribution and homogeneity of variances, and when necessary arcsin transformation was performed. Data were analysed by oneway ANOVA followed by Student-Newman-Keuls test at a significance level of $5 \%$. Also, the percentages of each fatty acid were chemometrically analysed by including them as variables in a multivariate principal components analysis (MPCA) model. With such a parsimonious approach, the dataset of variables (fatty acids) is reduced into a smaller set of factors or components. Parsimony is achieved by explaining the maximum amount of common variance in a correlation matrix using the smallest number of explanatory concepts. Factors are statistical entities that can be visualised as classification axes along which measurement variables can be plotted, giving an idea of their correlation with the corresponding factor (loading). Score plots are a graphical representation of individual (dietary groups) scores in the new subset of measurement variables (factors). They illustrate the relationship among individual cases (dietary groups), and the variables, and help in the analysis of data by showing graphical associations, or through new statistical analyses. In the present study, factor scores were subsequently analysed by one-way ANOVA and Student-Newman-Keuls 
multiple-comparison tests. All analyses were made using the SPSS package version 13.0 (SPSS Inc., Chicago, IL, USA).

\section{Results}

\section{Growth performance}

Fish grew from 16 to $240-270 \mathrm{~g}$ over a growth trial of 8 months' duration under natural light and temperature conditions (Fig. 1). The final body weight of fish fed the control diet did not differ from that of fish fed $33 \mathrm{VO}$ and $66 \mathrm{VO}$ diets, with overall specific growth rates ranging between 1.12 and $1 \cdot 16$ (see Table 3). By contrast, the total replacement of FO dictated a slight but significant reduction $(10 \%)$ of final body weight in fish fed the VO diet. A concurrent and significant decrease of voluntary feed intake (g DM intake) was found in fish fed the VO diet. Feed efficiency $(0.97-1.01)$ remained high and unchanged irrespective of dietary treatment.

\section{Tissue fat deposition and histological alterations}

After the summer replenishment of energy stores, lipid content of dorsal white muscle $(6-8 \%)$ was not affected by the dietary treatment. Hepatic fat content in fish fed control and $33 \mathrm{VO}$ diets was high and of the same order of magnitude ( $15 \%$ on wet-matter basis; $0.23-0.25 \mathrm{~g} / 100 \mathrm{~g}$ body weight). A progressive and significant increase (up to $25 \% ; 0.44 \mathrm{~g} / 100 \mathrm{~g}$
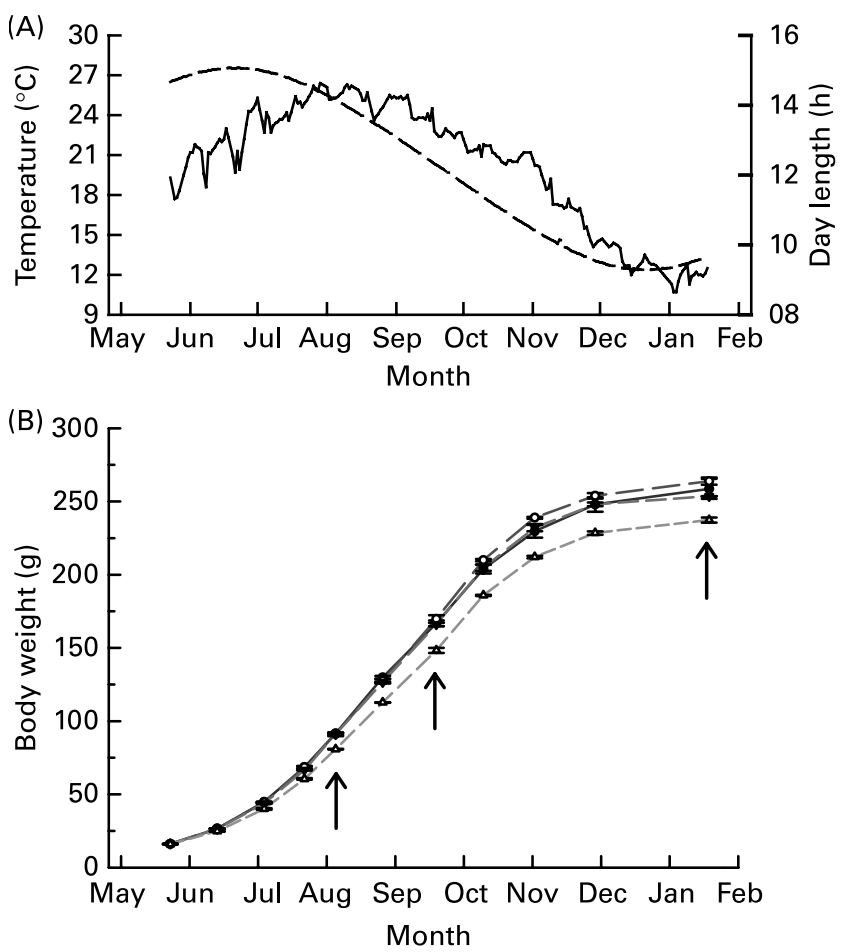

Fig. 1. (A) Seasonal changes of temperature (-) and day length (---) (B) Body weight over the course of the trial of fish fed the experimental diets. Jun, June; Jul, July; Aug, August; Sep, September; Oct, October; Nov, November; Dec, December; Jan, January; Feb, February; (-๑-), control diet;

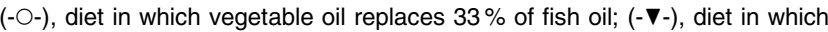
vegetable oil replaces $66 \%$ of fish oil; $(-\triangle-)$, diet in which vegetable oil replaces $100 \%$ of fish oil; $\uparrow$, tissue sampling times. Values are the means of triplicate tanks, with standard errors represented by vertical bars. body weight) was found with the graded replacement of FO in fish fed 66VO and VO diets (Fig. 2 (C)). However, signs of initial and localised lipoid liver disease were only found with the total replacement of FO with vegetable oils (Fig. 2 (A) and (B)). None of the FO-replaced diets produced apparent signs of histological damage in the intestine. Only one fish fed the VO diet had a moderate accumulation of lipid droplets in the intestinal epithelium that was not considered pathological.

\section{Muscle fatty acid profile}

The effects of dietary treatment upon muscle fatty acid profiles of TL are shown on a time-course basis (Table 4). Overall, fish fed the control diet contained $28 \%$ saturates (mainly $16: 0$ and $14: 0$ ), almost $32 \%$ monoenes (over half of which were $18: 1 n-9), 12 \% n-6$ fatty acids (predominantly $18: 2 n-6$ ) and 18-20\% $n-3$ HUFA (predominantly EPA and DHA). Increased amounts of $18: 1 n-9,18: 2 n-6$ and $18: 3 n-3$, in combination with reduced proportions of $n-3$ HUFA and saturated fatty acids, were found with the progressive replacement of FO by vegetable oils. The two first components of MPCA accounted for the $78 \%$ of variation of this dataset, although $67.9 \%$ of variation was explained by component 1 itself (Fig. 3 (A)). Thus, no grouping was recognised on the basis of sampling time (second factor score), whereas four groups were significantly separated (Student-Newman-Keuls; $P<0.05)$ and identified as the VO, 66VO, $33 \mathrm{VO}$ and control diets in the first factor score (Fig. 3 (B)).

The fatty acid profile of muscle PL of fish sampled at the end of the trial (January) is shown in Table 5. All experimental groups retained high amounts of SFA, predominantly 16:0 $(>13 \%)$ and $18: 0(>8 \%)$, but the relative amount of $18: 2 n-6$ increased up to $23 \%$ in fish fed the VO diet. A concurrent reduction in $n$-3 HUFA was also found, decreasing the EPA plus DHA content from 36 to $28 \%$ (fish fed control, $33 \mathrm{VO}$ and $66 \mathrm{VO}$ diets) to $16 \%$ (fish fed the VO diet). Thus, when data of PL and TL fractions were analysed by MPCA, the two principal components accounted for $67 \%$ of variation (Fig. 4 (A)). Component 1 explained $39.6 \%$ of variation and separated fatty acids that predominate in TL (on the left) from those characteristic of more unsaturated PL (on the right). Component 2 accounted for $27.8 \%$ of variation, and separated fatty acids representative of FO (above the zero line) from those characteristic of vegetable oils (below the zero line). The factor score plot separated TL and PL in the abscise axis, whereas grouping in the ordinate axis was based on the different effects of dietary intervention upon each lipid class. Accordingly, three major clusters were significantly separated (Student-Newman-Keuls; $P<0.05$ ) and identified in the first factor score plot as: (a) TL group, (b) $\mathrm{PL}$ of fish fed the VO diet and (c) a homogeneous group corresponding to PL of fish fed the control, $33 \mathrm{VO}$ and $66 \mathrm{VO}$ diets (Fig. 4 (B)).

\section{Discussion}

The demand for feed in intensive aquaculture has increased over recent years and extensive research has been done on alternative raw materials of vegetable origin. However, the main constraint for the use of vegetable oils in marine fish 
Table 3. Growth performance of fish fed the four experimental diets during 8 months (Mean values and standard deviations of triplicate tanks)

\begin{tabular}{|c|c|c|c|c|c|c|c|c|c|}
\hline & \multicolumn{8}{|c|}{ Diet } & \multirow[b]{3}{*}{$P^{*}$} \\
\hline & \multicolumn{2}{|c|}{ Control } & \multicolumn{2}{|c|}{$33 \mathrm{VO}$} & \multicolumn{2}{|c|}{$66 \mathrm{VO}$} & \multicolumn{2}{|c|}{ vo } & \\
\hline & Mean & SD & Mean & SD & Mean & SD & Mean & SD & \\
\hline Initial body weight (g) & $16 \cdot 10$ & 0.09 & $16 \cdot 30$ & 0.01 & $16 \cdot 30$ & 0.03 & $16 \cdot 10$ & 0.09 & 0.31 \\
\hline Final body weight (g) & $257 \cdot 80^{\mathrm{a}, \mathrm{b}}$ & 11.84 & $269.57^{b}$ & $2 \cdot 41$ & $253.72^{\mathrm{a}}$ & 0.16 & $237.39^{\mathrm{c}}$ & 3.07 & $<0.05$ \\
\hline DM intake (g/fish) & $238 \cdot 35^{\mathrm{a}}$ & $6 \cdot 68$ & $256.87^{b}$ & 4.42 & $241.59^{\mathrm{a}}$ & $2 \cdot 69$ & $226 \cdot 11^{\mathrm{c}}$ & 0.62 & $<0.001$ \\
\hline SGR (\%)† & $1 \cdot 14^{\mathrm{a}, \mathrm{b}}$ & 0.01 & $1 \cdot 16^{\mathrm{a}}$ & 0.00 & $1 \cdot 13^{\mathrm{b}}$ & 0.00 & $1.11^{\mathrm{c}}$ & 0.00 & $<0.05$ \\
\hline FE $\ddagger$ & 1.01 & 0.02 & 0.98 & 0.00 & 0.98 & 0.01 & 0.97 & 0.01 & 0.07 \\
\hline
\end{tabular}

$33 \mathrm{VO}$ diet, diet in which vegetable oil replaces $33 \%$ of fish oil; $66 \mathrm{VO}$, diet in which vegetable oil replaces $66 \%$ of fish oil; VO diet, diet in which vegetable oil replaces $100 \%$ of fish oil; SGR, specific growth ratio; FE, feed efficiency.

a,b,c Mean values within a row with unlike superscript letters were significantly different $(P<0.05$; Student-Newman-Keuls).

${ }^{*} P$ values result from one-way ANOVA.

†SGR $=(100 \times($ In final fish wt - In initial fish wt $)) / d$.

$\ddagger \mathrm{FE}=$ wet wt gain/dry feed intake.

feeds is the lack of $n$-3 long-chain PUFA, particularly EPA and DHA. Moreover, quantitative requirements depend on species and growth rates, and the biological demand for $n-3$ HUFA was at least $1.6 \%$ of DM for flatfish larvae ${ }^{(33)}$ decreasing to $0 \cdot 8-0.6 \%$ in juvenile ${ }^{(34,35)}$ and grower fish ${ }^{(36)}$. Similar requirements were reported for juvenile European sea bass ${ }^{(37)}$ and gilthead sea bream ${ }^{(38)}$. In the present study the theoretical requirements of EFA were met by $33 \mathrm{VO}(1.6 \% \mathrm{EPA}+\mathrm{DHA})$ and $66 \mathrm{VO}(0.9 \% \mathrm{EPA}+\mathrm{DHA})$ diets, but not by the VO diet $(0.3 \%$ EPA + DHA). Thereby, in this and in a previous short-term trial ${ }^{(27)}$, no detrimental effects on growth performance were found with the replacement of up to $66 \%$ of the added FO, whereas a slight but significant reduction in feed intake and weight gain was found with the total FO replacement, indicating that a dietary supply of $0.3 \%$ of $\mathrm{EPA}+\mathrm{DHA}$ was not sufficient for normal growth and development of gilthead sea bream. However, fishmeal itself contains appreciable amounts of FO, and trials conducted in our experimental facilities show that the total replacement of the added FO is feasible without adverse effects on growth in gilthead sea bream diets with a 30-35\% fishmeal inclusion (L Benedito-Palos, JC Navarro, A Sitjá-Bobadilla, JG Bell,
(A)

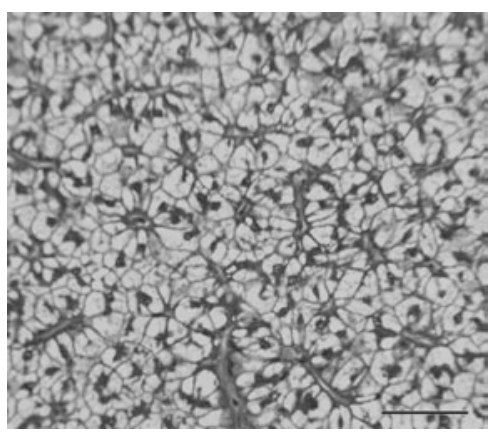

(B)

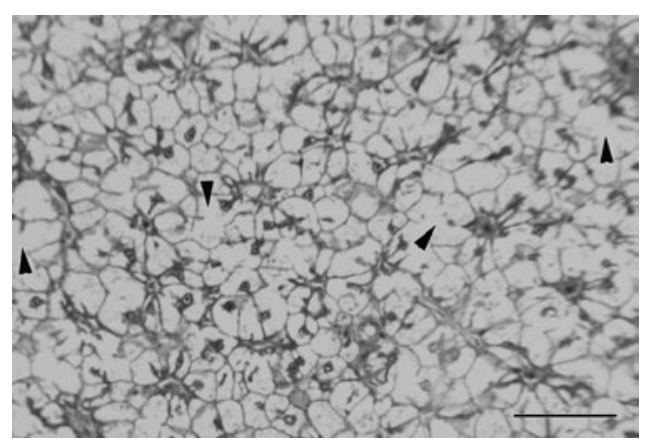

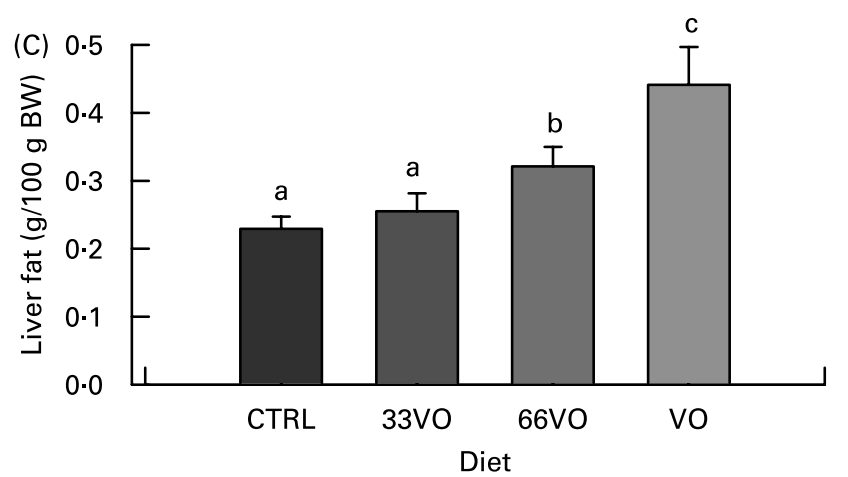

Fig. 2. Representative histological sections of livers of fish sampled in September after 18 weeks of feeding the experimental diets: (A) control (CTRL) diet; (B) diet in which vegetable oil replaces $100 \%$ of fish oil (VO diet) (staining by toluidine blue; scale bars $=50 \mu \mathrm{m}$ ). Notice the lipoid liver degeneration with breakdown of hepatocyte membranes $(\rightarrow)$. Liver fat content $(C)$ of fish fed the four experimental diets (18 weeks). BW, body weight; $33 \mathrm{VO}$ diet, diet in which vegetable oil replaces $33 \%$ of fish oil; $66 \mathrm{VO}$, diet in which vegetable oil replaces $66 \%$ of fish oil. Values are means, with standard errors represented by vertical bars. a,b,c Mean values with unlike letters were significantly different $(P<0.05$; Student-Newman-Keuls). 
Table 4. Effects of the feeding regimen on the muscle fatty acid profile of total lipids (\% of total fatty acid methyl esters) in fish sampled in August, September and January (Mean values and standard deviations of ten fish)

\begin{tabular}{|c|c|c|c|c|c|c|c|c|c|c|c|c|c|c|c|c|c|c|c|c|c|c|c|c|}
\hline \multirow[b]{3}{*}{ Fatty acids } & \multicolumn{6}{|c|}{ Control diet } & \multicolumn{6}{|c|}{$33 \mathrm{VO}$ diet } & \multicolumn{6}{|c|}{$66 \mathrm{VO}$ diet } & \multicolumn{6}{|c|}{ VO diet } \\
\hline & \multicolumn{2}{|c|}{ August } & \multicolumn{2}{|c|}{ September } & \multicolumn{2}{|c|}{ January } & \multicolumn{2}{|c|}{ August } & \multicolumn{2}{|c|}{ September } & \multicolumn{2}{|c|}{ January } & \multicolumn{2}{|c|}{ August } & \multicolumn{2}{|c|}{ September } & \multicolumn{2}{|c|}{ January } & \multicolumn{2}{|c|}{ August } & \multicolumn{2}{|c|}{ September } & \multicolumn{2}{|c|}{ January } \\
\hline & Mean & SD & Mean & SD & Mean & SD & Mean & SD & Mean & SD & Mean & SD & Mean & SD & Mean & SD & Mean & SD & Mean & SD & Mean & SD & Mean & SD \\
\hline $14: 0$ & $3.70^{\mathrm{a}}$ & 0.22 & $3.67^{\mathrm{a}}$ & 0.63 & $4 \cdot 52^{\mathrm{b}}$ & 0.36 & 2.48 & 0.41 & 2.54 & 0.41 & 2.60 & 0.42 & 1.79 & 0.16 & 1.62 & 0.15 & 1.77 & 0.31 & 0.90 & 0.12 & 0.79 & 0.12 & $1 \cdot 12$ & 0.45 \\
\hline $16: 0$ & $20 \cdot 40^{\mathrm{a}}$ & 0.74 & $20 \cdot 10^{\mathrm{a}}$ & 0.81 & $18 \cdot 30^{\mathrm{b}}$ & 0.98 & $20 \cdot 60^{\mathrm{a}}$ & 0.79 & $19 \cdot 00^{\mathrm{b}}$ & 0.79 & $19 \cdot 00^{\mathrm{b}}$ & 0.44 & $17 \cdot 80^{\mathrm{a}}$ & 0.89 & $19 \cdot 00^{\mathrm{b}}$ & 0.90 & $17 \cdot 20^{\mathrm{a}}$ & 0.62 & 15.80 & 0.58 & $16 \cdot 20$ & 0.34 & $16 \cdot 10$ & 0.53 \\
\hline $16: 1 n-7$ & 4.75 & 0.28 & 4.58 & 0.74 & 5.38 & 0.52 & 3.60 & 0.51 & 3.65 & 0.51 & 3.64 & 0.50 & 2.93 & $0 \cdot 18$ & 2.56 & 0.21 & 2.85 & 0.38 & 1.77 & 0.34 & 1.52 & 0.21 & $2 \cdot 15$ & 0.52 \\
\hline $16: 2$ & 0.25 & 0.02 & 0.25 & 0.02 & 0.28 & 0.02 & 0.13 & 0.05 & 0.18 & 0.05 & 0.15 & 0.02 & 0.08 & 0.03 & 0.13 & 0.04 & 0.11 & 0.03 & $\operatorname{tr}$ & & $\operatorname{tr}$ & & 0.11 & 0.00 \\
\hline $16: 3$ & 0.19 & 0.06 & 0.22 & 0.04 & 0.23 & 0.02 & 0.15 & 0.01 & 0.16 & 0.01 & 0.14 & 0.04 & 0.12 & 0.06 & 0.08 & 0.02 & 0.10 & 0.04 & 0.08 & 0.04 & 0.09 & 0.01 & 0.09 & 0.01 \\
\hline $16: 4$ & 0.18 & 0.02 & 0.15 & 0.04 & 0.15 & 0.01 & 0.11 & 0.03 & 0.11 & 0.03 & $0 \cdot 10$ & 0.02 & 0.07 & 0.01 & 0.06 & 0.00 & 0.08 & 0.06 & $\operatorname{tr}$ & & 0.07 & 0.02 & 0.13 & 0.05 \\
\hline $17: 0$ & 0.22 & 0.02 & 0.26 & 0.05 & 0.23 & 0.01 & 0.20 & 0.04 & 0.18 & 0.04 & 0.19 & 0.02 & 0.12 & 0.06 & 0.18 & 0.01 & 0.21 & 0.06 & 0.14 & 0.56 & 0.14 & 0.56 & 0.13 & 0.01 \\
\hline $18: 0$ & $3.82^{\mathrm{a}}$ & 0.38 & $3.96^{\mathrm{a}}$ & 0.66 & $3.00^{\mathrm{b}}$ & 0.26 & 4.57 & 0.74 & 4.32 & 0.74 & 4.10 & 0.55 & 4.15 & 0.56 & 4.88 & 0.48 & 3.92 & 0.64 & 4.53 & 0.36 & 4.92 & 1.67 & 4.40 & 0.66 \\
\hline $18: 1 n-9$ & $17 \cdot 40$ & 0.56 & 16.00 & 0.86 & 16.80 & 0.98 & $20 \cdot 40$ & 1.40 & $20 \cdot 60$ & 1.41 & 18.50 & 2.85 & 25.00 & 1.61 & 23.80 & 0.91 & 24.50 & $2 \cdot 25$ & 28.20 & 0.78 & 27.50 & 0.08 & $27 \cdot 30$ & 3.06 \\
\hline $18: 1 n-7$ & 1.87 & 0.08 & 1.84 & 0.10 & 1.93 & 0.07 & 1.59 & 0.20 & 1.75 & 0.19 & 1.55 & 0.05 & 1.38 & 0.02 & 1.30 & 0.04 & 1.36 & 0.04 & $1 \cdot 10$ & 0.06 & 1.09 & 0.85 & 1.22 & 0.13 \\
\hline $18: 2 n-6$ & $10 \cdot 70^{\mathrm{a}}$ & 0.12 & $10 \cdot 60^{\mathrm{a}}$ & 0.65 & $11 \cdot 80^{\mathrm{b}}$ & 0.19 & $12 \cdot 80^{\mathrm{a}}$ & 0.93 & $13 \cdot 40^{\mathrm{a}, \mathrm{b}}$ & 0.93 & $14 \cdot 90^{\mathrm{b}}$ & 1.56 & $16 \cdot 30^{\mathrm{a}}$ & 0.46 & $16 \cdot 60^{\mathrm{a}}$ & 0.33 & $17 \cdot 40^{\mathrm{b}}$ & 0.15 & 19.40 & 0.52 & 20.40 & 1.54 & 20.50 & 1.66 \\
\hline $18: 3 n-3$ & 1.06 & 0.12 & 0.98 & 0.09 & 1.07 & 0.05 & 5.65 & 0.83 & 6.42 & 0.83 & 5.80 & 0.64 & $12 \cdot 20$ & $1 \cdot 15$ & 11.00 & 1.19 & $12 \cdot 10$ & 1.50 & 17.80 & 0.76 & 16.80 & 0.11 & 15.80 & 1.75 \\
\hline $18: 4 n-3$ & 1.28 & 0.08 & 1.22 & 0.22 & 1.38 & 0.10 & 0.89 & 0.20 & 1.00 & 0.20 & 0.83 & 0.13 & 0.81 & 0.12 & 0.64 & 0.15 & 0.77 & 0.12 & 0.63 & 0.08 & 0.51 & 0.03 & 0.55 & 0.13 \\
\hline $20: 0$ & 0.18 & 0.02 & 0.18 & 0.02 & 0.18 & 0.01 & 0.17 & 0.06 & 0.20 & 0.06 & 0.17 & 0.02 & 0.16 & 0.01 & 0.16 & 0.01 & 0.17 & 0.01 & 0.15 & 0.01 & 0.17 & 0.10 & 0.16 & 0.01 \\
\hline $20: 1 n-9$ & 4.90 & 0.40 & 4.79 & 0.84 & 5.53 & 0.22 & 3.25 & 0.50 & 3.15 & 0.46 & 3.25 & 0.01 & 1.92 & 0.53 & 1.86 & 0.26 & 1.91 & 0.29 & 0.91 & 0.04 & 0.92 & 0.08 & 0.93 & 0.52 \\
\hline $20: 2 n-6$ & 0.22 & 0.00 & 0.24 & 0.02 & 0.25 & 0.03 & 0.23 & 0.06 & 0.28 & 0.02 & 0.26 & 0.01 & 0.27 & 0.01 & 0.27 & 0.03 & 0.27 & 0.03 & 0.28 & 0.02 & 0.33 & 0.03 & 0.33 & 0.03 \\
\hline $20: 3 n-6$ & 0.17 & 0.02 & 0.12 & 0.06 & 0.13 & 0.01 & 0.16 & 0.02 & 0.16 & 0.06 & 0.18 & 0.03 & 0.19 & 0.05 & 0.19 & 0.04 & 0.18 & 0.07 & 0.18 & 0.04 & 0.23 & 0.10 & 0.22 & 0.10 \\
\hline $20: 3 n-3$ & 0.07 & 0.00 & 0.09 & 0.03 & 0.08 & 0.00 & $0.12^{\mathrm{a}}$ & 0.05 & $0.17^{b}$ & 0.05 & $0.16^{\mathrm{b}}$ & 0.01 & $0.27^{\mathrm{a}, \mathrm{b}}$ & 0.02 & $0.23^{\mathrm{a}}$ & 0.04 & $0.29^{b}$ & 0.04 & 0.40 & 0.06 & 0.45 & 0.07 & 0.48 & 0.09 \\
\hline $20: 4 n-6$ & $0.49^{\mathrm{a}}$ & 0.02 & $0.54^{\mathrm{a}}$ & 0.16 & $0.38^{\mathrm{b}}$ & 0.08 & 0.49 & 0.10 & 0.41 & 0.02 & 0.42 & 0.09 & 0.26 & 0.10 & 0.30 & 0.05 & 0.24 & 0.12 & 0.18 & 0.04 & 0.17 & 0.09 & 0.17 & 0.09 \\
\hline $20: 4 n-3$ & 0.58 & 0.06 & 0.59 & 0.07 & 0.66 & 0.04 & 0.49 & 0.00 & 0.52 & 0.15 & 0.52 & 0.06 & 0.47 & 0.03 & 0.39 & 0.05 & 0.45 & 0.05 & 0.34 & 0.04 & 0.34 & 0.39 & 0.35 & 0.05 \\
\hline $20: 5 n-3$ & 6.06 & 0.42 & $6 \cdot 40$ & 0.85 & 5.02 & 0.37 & 4.87 & 0.93 & 4.58 & 0.03 & 4.34 & 0.72 & 2.83 & 0.55 & 3.06 & 0.29 & 2.56 & 0.76 & 1.41 & 0.24 & 1.34 & 0.05 & 1.55 & 0.74 \\
\hline $22: 1 n-9$ & 0.62 & 0.08 & 0.31 & 0.08 & 0.42 & 0.03 & 0.22 & 0.10 & 0.29 & 0.93 & 0.26 & 0.03 & 0.20 & 0.15 & 0.11 & 0.02 & 0.28 & 0.12 & 0.10 & 0.15 & 0.09 & 0.03 & 0.14 & 0.04 \\
\hline $22: 1 n-11$ & 4.83 & 0.66 & 4.73 & 1.05 & 5.35 & 0.51 & 2.62 & 0.60 & 2.91 & 0.15 & $2 \cdot 78$ & 0.46 & 1.65 & 0.31 & 1.46 & 0.28 & 1.62 & 0.40 & 0.27 & 0.12 & 0.30 & 0.05 & 0.33 & 0.09 \\
\hline $22: 5 n-3$ & 1.31 & 0.10 & 1.37 & 0.10 & 1.51 & 0.11 & $1 \cdot 10$ & 0.07 & 1.06 & 0.08 & 1.25 & 0.15 & 0.80 & 0.17 & 0.63 & $0 \cdot 10$ & 0.69 & 0.41 & 0.36 & 0.1 & 0.32 & 0.17 & 0.45 & 0.09 \\
\hline $22: 6 n-3$ & 10.80 & 1.00 & 12.40 & 2.79 & $10 \cdot 60$ & 2.05 & 9.74 & $2 \cdot 32$ & 8.85 & 0.63 & 11.00 & 2.67 & 5.75 & 1.77 & 6.54 & 0.82 & 6.02 & 2.58 & 3.11 & 0.5 & 3.15 & $1 \cdot 15$ & 3.52 & 1.82 \\
\hline $24: 1 n-9$ & $0.56^{\mathrm{a}}$ & 0.08 & $0.40^{\mathrm{b}}$ & 0.04 & $0.41^{\mathrm{b}}$ & 0.04 & $0.56^{\mathrm{a}}$ & 0.03 & $0.40^{\mathrm{b}}$ & 0.07 & $0.35^{\mathrm{b}}$ & 0.08 & $0.40^{\mathrm{a}}$ & 0.04 & $0.38^{\mathrm{a}}$ & 0.04 & $0.32^{\mathrm{b}}$ & 0.03 & 0.29 & 0.02 & 0.29 & 0.03 & 0.35 & 0.06 \\
\hline Saturates & $28.32^{\mathrm{a}}$ & 1.05 & $28 \cdot 17^{\mathrm{a}}$ & 0.81 & $26 \cdot 23^{b}$ & 0.90 & 28.02 & 1.86 & $26 \cdot 24$ & 1.22 & 26.06 & 0.57 & $24.02^{\mathrm{a}}$ & 1.32 & $25 \cdot 84^{\mathrm{b}}$ & 1.24 & $23 \cdot 27^{\mathrm{a}}$ & 0.97 & 21.52 & 0.78 & $22 \cdot 22$ & 0.77 & 21.91 & 0.93 \\
\hline Monoenes & 34.93 & 1.46 & 32.65 & 3.61 & 35.82 & 1.92 & $32 \cdot 24$ & 3.36 & 32.75 & 2.93 & 30.33 & 4.07 & 33.48 & 2.43 & 31.47 & 1.09 & 32.84 & 3.41 & 32.64 & 0.96 & 31.71 & 1.97 & 32.42 & 3.35 \\
\hline$n-3$ HUFA $^{*}$ & 18.82 & 1.48 & 20.85 & 3.59 & 17.87 & $2 \cdot 38$ & $16 \cdot 32$ & $3 \cdot 14$ & $15 \cdot 18$ & 3.26 & $17 \cdot 27$ & 3.44 & 10.12 & 2.49 & 10.85 & 1.23 & 10.01 & 3.73 & 5.62 & 0.81 & 5.60 & 1.61 & 6.35 & 2.75 \\
\hline$n-6$ HUFA $\dagger$ & 0.88 & $1 \cdot 13$ & 0.09 & 0.11 & 0.76 & 0.06 & 0.88 & 0.11 & 0.85 & 0.22 & 0.86 & 0.11 & 0.72 & 0.15 & 0.76 & 0.13 & 0.69 & 0.19 & 0.64 & 0.07 & 0.73 & 0.18 & 0.72 & 0.20 \\
\hline
\end{tabular}

$33 \mathrm{VO}$ diet, diet in which vegetable oil replaces $33 \%$ of fish oil; $66 \mathrm{VO}$, diet in which vegetable oil replaces $66 \%$ of fish oil; VO diet, diet in which vegetable oil replaces $100 \%$ of fish oil; tr, trace value $<0.05$; HUFA, highly unsaturated fatty acids.

${ }_{a, b}$ Mean values within a row with unlike superscript letters were significantly different $(P<0.05$; Student-Newman-Keuls)

Calculated excluding $18 \mathrm{C}$ atoms of the $n-3$ series.

tCalculated excluding $18 \mathrm{C}$ atoms of the $n-6$ series. 

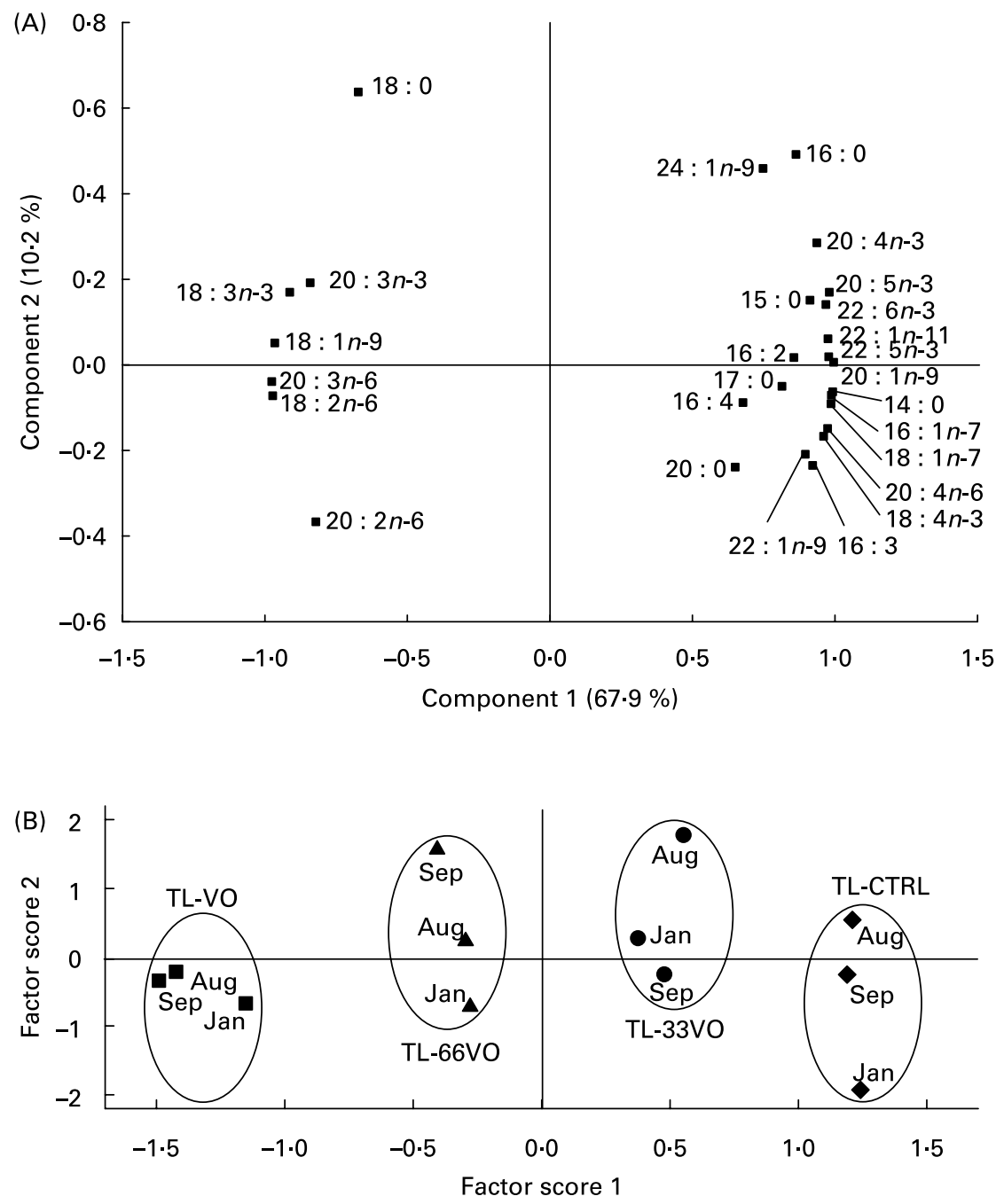

Fig. 3. Component plot (A) and factor score plot (B) of the multivariate principal components analysis for the muscle fatty acid profile of total lipids (TL) in fish sampled in August (Aug), September (Sep) and January (Jan). VO, diet in which vegetable oil replaces $100 \%$ of fish oil; 66VO, diet in which vegetable oil replaces $66 \%$ of fish oil; $33 \mathrm{VO}$, diet in which vegetable oil replaces $33 \%$ of fish oil; CTRL, control diet. Mean values are shown in the factor score plot to simplify the graph representation. Ovals stand for different clusters in the factor score $1(P<0.05$; Student-Newman-Keuls).

S Kaushik and J Pérez-Sánchez, unpublished results). Regost et al. ${ }^{(39)}$ also reported the feasibility of the total replacement of FO by vegetable oils in turbot fed fishmeal-based diets. Similar results were reported in sharpsnout sea bream by Piedecausa et al. ${ }^{(40)}$ However, in the present study, we report for the first time, over the production cycle of a marine fish, the use of well-balanced plant protein diets with a low inclusion of marine raw materials $(<20 \%)$ just to cover EFA needs.

It is noteworthy that growth rates in the trial conducted in the present study were excellent and even improved upon the values reported for fish of the same size class under similar experimental conditions ${ }^{(25,26,41,42)}$. This fact can be attributed to the genetic improvement of fish strains but also to better fish management, culture conditions and dietary formulation. Since fishmeal is also a source of PL, the plant protein mixture in the present study was adequately supplemented with amino acids and PL supplied in the form of soya lecithin. This added component is rich in phosphatidylcholine, a polar lipid molecule that is a natural component of lipoproteins and cellular membranes, adding fluidity and rigidity to cells as well as being required for lipoprotein synthesis, lipid mobilisation and digestibility. Our experimental design does not delineate unequivocally the beneficial effects of soya lecithin, but it must be noted that signs of intestine damage and transport dysfunction (massive accumulation of lipid droplets) were not found in any experimental group. By contrast, intense accumulation of lipid droplets was reported earlier in the hindgut of juvenile gilthead sea bream fed plant protein and FObased diets without PL supplementation ${ }^{(43)}$. Similar histological alterations have been reported by other authors using transmission electron microscopy ${ }^{(15)}$ and, interestingly, earlier studies in young larvae demonstrated that dietary lecithin increases the appearance of lipoproteins and enhances the lipid transport through the gut ${ }^{(12,44,45)}$. Likewise, intense accumulation of lipid droplets was seen in the gastrointestinal tract of salmonids fed with plant oils, but this condition was reversed by PL supplementation ${ }^{(13,14)}$.

Defects in fatty acid storage and oxidation are a central initiating factor for metabolic and endocrine alterations, 
Table 5. Effects of the feeding regimen on the muscle fatty acid profile of phospholipids (\% of total fatty acid methyl esters) in fish sampled at the end of the trial (January)

(Mean values and standard deviations of ten fish)

\begin{tabular}{|c|c|c|c|c|c|c|c|c|}
\hline \multirow[b]{3}{*}{ Fatty acids } & \multicolumn{8}{|c|}{ Diet } \\
\hline & \multicolumn{2}{|c|}{ Control } & \multicolumn{2}{|c|}{$33 \mathrm{VO}$} & \multicolumn{2}{|c|}{$66 \mathrm{VO}$} & \multicolumn{2}{|c|}{ VO } \\
\hline & Mean & SD & Mean & SD & Mean & SD & Mean & SD \\
\hline $14: 0$ & 0.62 & 0.20 & 0.57 & 0.51 & 0.54 & 0.24 & 0.23 & 0.07 \\
\hline $16: 0$ & $18 \cdot 4^{\mathrm{a}}$ & $1 \cdot 22$ & $17 \cdot 50^{a, b}$ & $1 \cdot 19$ & $16 \cdot 50^{b}$ & 0.96 & $13 \cdot 2^{c}$ & 0.38 \\
\hline $16: 1 n-7$ & 1.06 & 0.36 & 0.80 & $0 \cdot 12$ & 0.70 & 0.17 & 0.76 & 0.23 \\
\hline $16: 2$ & $0.30^{\mathrm{a}}$ & 0.15 & $0.25^{a, b}$ & 0.12 & $0.23^{b}$ & 0.00 & $0.22^{b}$ & 0.00 \\
\hline $16: 3$ & 0.34 & 0.00 & 0.20 & $0 \cdot 14$ & 0.36 & 0.06 & 0.16 & 0.13 \\
\hline $16: 3 n-3$ & $1 \cdot 76$ & 1.43 & 0.62 & 0.48 & $1 \cdot 12$ & 1.01 & 0.81 & 0.33 \\
\hline $16: 4$ & 0.30 & 0.07 & 0.29 & 0.10 & 0.39 & 0.09 & 0.42 & 0.07 \\
\hline $17: 0$ & 0.38 & 0.13 & 0.30 & 0.17 & 0.34 & 0.04 & 0.26 & 0.14 \\
\hline $18: 0$ & $10 \cdot 10$ & $1 \cdot 24$ & 8.42 & 0.75 & $10 \cdot 20$ & $1 \cdot 12$ & 8.44 & 0.69 \\
\hline $18: 1 n-9$ & $7.59^{a}$ & 0.14 & $9 \cdot 33^{b}$ & 0.02 & $10 \cdot 20^{b}$ & 0.06 & $13 \cdot 40^{\mathrm{C}}$ & 0.08 \\
\hline $18: 1 n-7$ & $1 \cdot 84$ & 0.41 & 1.66 & 0.62 & 1.54 & 0.92 & 0.82 & 0.61 \\
\hline $18: 2 n-6$ & $7 \cdot 26^{a}$ & 0.74 & $10 \cdot 90^{b}$ & 1.42 & $14 \cdot 20^{c}$ & 0.92 & $23 \cdot 30^{d}$ & 1.79 \\
\hline $18: 3 n-3$ & $0.45^{\mathrm{a}}$ & 0.26 & $2 \cdot 29^{b}$ & 0.18 & $4.88^{c}$ & 0.41 & $10 \cdot 20^{d}$ & $1 \cdot 11$ \\
\hline $18: 4 n-3$ & $0 \cdot 31$ & 0.25 & 0.29 & 0.29 & 0.30 & 0.11 & 0.29 & 0.11 \\
\hline $20: 0$ & 0.27 & 0.00 & 0.16 & 0.03 & 0.26 & 0.00 & 0.30 & 0.13 \\
\hline $20: 1 n-9$ & $2.42^{\mathrm{a}}$ & 0.25 & $1.67^{b}$ & 0.20 & $1.09^{c}$ & 0.18 & $0.57^{d}$ & 0.27 \\
\hline $20: 2 n-6$ & 0.40 & 0.14 & 0.44 & 0.30 & 0.65 & 0.26 & 0.80 & 0.60 \\
\hline $20: 3 n-6$ & 0.54 & 0.44 & 0.38 & 0.20 & 0.41 & 0.08 & 0.68 & 0.06 \\
\hline $20: 3 n-3$ & $0.53^{a}$ & 0.48 & $0 \cdot 24^{a}$ & 0.21 & $0.34^{a}$ & 0.12 & $0.87^{b}$ & 0.19 \\
\hline $20: 4 n-6$ & 0.94 & 0.05 & $1 \cdot 15$ & 0.07 & 0.87 & 0.28 & 0.65 & 0.08 \\
\hline $20: 4 n-3$ & 0.43 & 0.43 & 0.51 & 0.20 & 0.57 & 0.14 & 0.53 & 0.18 \\
\hline $20: 5 n-3$ & $7 \cdot 08^{a}$ & 0.64 & $7 \cdot 52^{a}$ & 0.44 & $6 \cdot 32^{b}$ & 0.42 & $3.72^{c}$ & 0.19 \\
\hline $22: 1 n-11$ & 0.68 & 0.38 & 0.40 & 0.31 & 0.37 & 0.28 & 0.36 & 0.29 \\
\hline $22: 5 n-3$ & $1.93^{a}$ & 0.07 & $2.05^{a}$ & 0.15 & $1.64^{b}$ & 0.22 & $1 \cdot 23^{c}$ & 0.20 \\
\hline $22: 6 n-3$ & $29 \cdot 00^{a}$ & 3.62 & $27 \cdot 80^{a}$ & $3 \cdot 26$ & $21 \cdot 40^{b}$ & 2.06 & $12 \cdot 60^{\mathrm{C}}$ & 0.52 \\
\hline $24: 1 n-9$ & 0.76 & 0.24 & 0.52 & 0.25 & 0.59 & 0.07 & 0.41 & 0.18 \\
\hline Saturates & $29 \cdot 77^{a}$ & $1 \cdot 75$ & $26.95^{b}$ & 0.55 & $27 \cdot 84^{a, b}$ & 1.94 & $22 \cdot 43^{c}$ & 0.95 \\
\hline Monoenes & $14 \cdot 35^{a}$ & 0.83 & $14 \cdot 38^{a}$ & 0.73 & $14.49^{a}$ & 0.84 & $16 \cdot 32^{b}$ & 0.33 \\
\hline$n-3$ HUFA $^{*}$ & $38.97^{a}$ & $3 \cdot 39$ & $38 \cdot 12^{\mathrm{a}}$ & $3 \cdot 17$ & $30 \cdot 27^{b}$ & $2 \cdot 62$ & $18 \cdot 95^{\mathrm{C}}$ & 0.78 \\
\hline$n-6$ HUFA† & $1 \cdot 88$ & 0.79 & 1.97 & 0.68 & 1.93 & 0.47 & $2 \cdot 13$ & 0.96 \\
\hline n-3:n-6 Ratio $\neq$ & $4 \cdot 34^{\mathrm{a}}$ & 0.33 & $3 \cdot 16^{b}$ & 0.09 & $2 \cdot 19^{c}$ & 0.06 & $1 \cdot 15^{d}$ & 0.02 \\
\hline
\end{tabular}

$33 \mathrm{VO}$ diet, diet in which vegetable oil replaces $33 \%$ of fish oil; $66 \mathrm{VO}$, diet in which vegetable oil replaces $66 \%$ of fish oil; VO diet, diet in which vegetable oil replaces $100 \%$ of fish oil; HUFA, highly unsaturated fatty acids.

a,b,c,d Mean values within a row with unlike superscript letters were significantly different $(P<0.05$; Student-Newman-Keuls).

${ }^{*}$ Calculated excluding $18 \mathrm{C}$ atoms of the $n-3$ series.

† Calculated excluding $18 \mathrm{C}$ atoms of the $n-6$ series.

$\ddagger$ Calculated taking into account all $n-3$ and $n-6$ fatty acid series.

resulting in enhanced fatty acid flux from adipose tissue towards liver and muscle ${ }^{(46,47)}$. Ration size by itself is also a major disrupting factor, and long-term feeding close to satiation increases hepatic fat deposition in gilthead sea bream juveniles, leading to lipoid liver disease and enterocyte desquamation in fish fed commercial diets ${ }^{(48)}$. Dietary inclusion of vegetable oils ${ }^{(49,50)}$ and plant proteins ${ }^{(43)}$ also induces lipoid liver disease, and the role of $\mathrm{TNF} \alpha$ and lipoprotein lipase as lipolytic cytokines and rate-limiting enzymes in tissue fatty acid uptake has been reported in gilthead sea bream $^{(51,52)}$. Precise effects of nutrients on the dysregulation of lipid metabolic pathways still remain largely unknown, but several studies indicate that soyabean phosphatidylcholine may alleviate signs of liver diseases, promoting a healthy lipid metabolism ${ }^{(12,53,54)}$. This notion is supported in the present study by the observation that hepatic fat deposition varied between 15 and $25 \%$ of wet weight, though signs of initial and focal lipoid liver disease were only found with the total FO replacement. By contrast, clear signs of liver disease have been reported with a liver fat deposition below $15 \%$ in fish fed $16 \%$ lipid diets ${ }^{(43)}$ (22\% lipid diets were used in the present study). This finding suggests that the fat threshold level for liver damage was significantly increased in the present study. However, the extent to which this condition is due to PL supplementation with soya lecithin rather than to other poorly defined dietary factors merits more specific research.

The gilthead sea bream, as other poikilotherms, utilises favourable conditions in summer for rapid growth and replenishment of energy stores, but analyses of fatty acid profiles in this and other fish species including Atlantic salmon ${ }^{(55,56)}$ rainbow trout ${ }^{(57)}$, turbot ${ }^{(39)}$ and European sea bass ${ }^{(58,59)}$ suggest a selective incorporation of $n-3$ PUFA in polar lipids and perhaps increased oxidation rates of other more easily utilisable fatty acids. Moreover, the seasonal cycling increases in fat storage alter the ratio of polar and neutral lipids, driving the well-reported changes in the muscle fatty acid profile seen in wild gilthead sea bream ${ }^{(21)}$. In addition, there is experimental evidence linking fatty acid profiles of wild brown trout with the trophic level of the species, the location of the catch, and the size and physiological status 

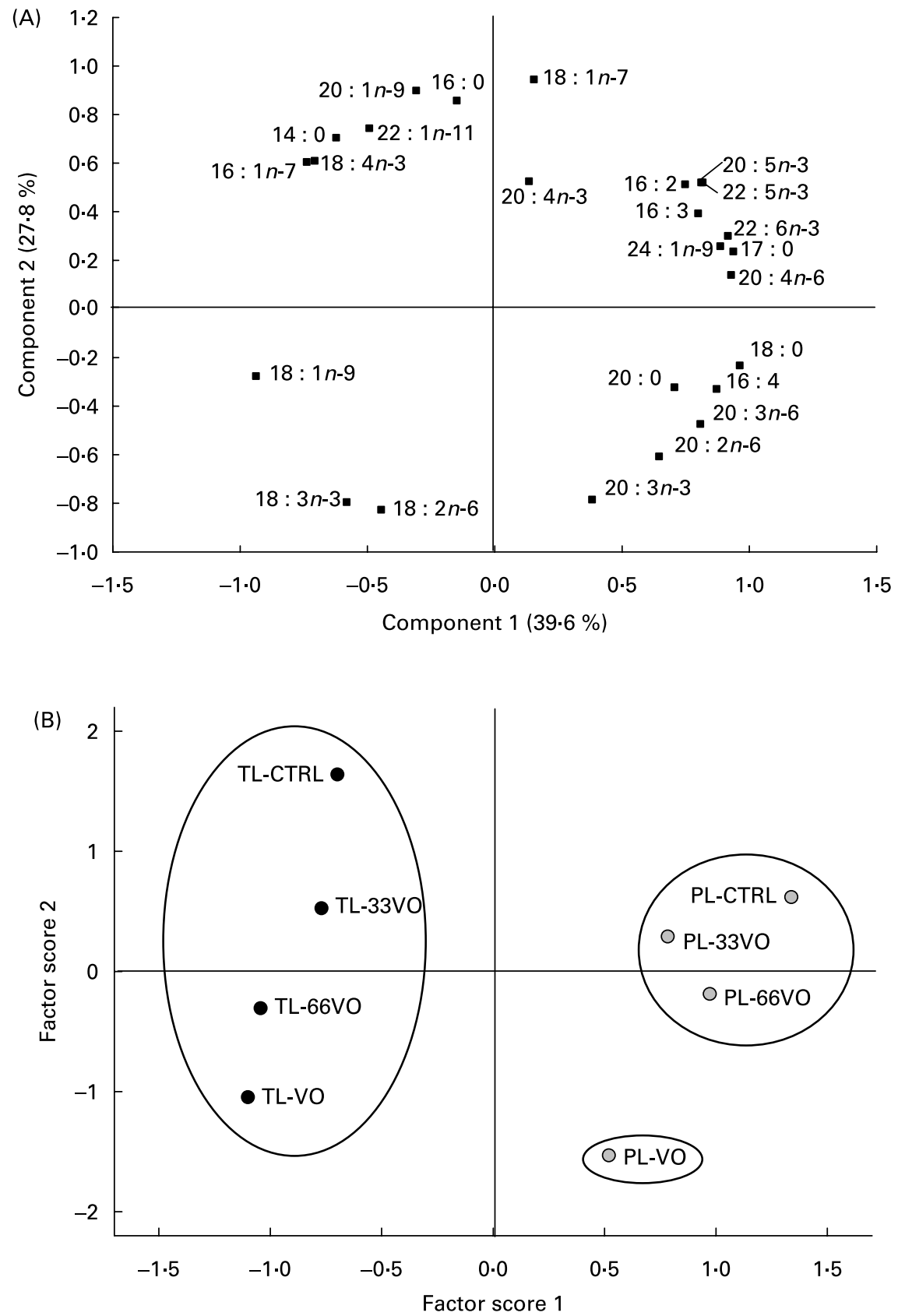

Fig. 4. Component plot (A) and factor score plot (B) of the multivariate principal components analysis for the muscle fatty acid profile of total lipids (TL; $\bullet$ ) and phospholipids (PL; O) (January-sampled fish). CTRL, control diet; 33VO, diet in which vegetable oil replaces $33 \%$ of fish oil; $66 \mathrm{VO}$, diet in which vegetable oil replaces $66 \%$ of fish oil; VO, diet in which vegetable oil replaces $100 \%$ of fish oil. Mean values are shown in the factor score plot to simplify the graph representation. Ovals stand for different clusters in the factor score $1(P<0.05$; Student-Newman-Keuls).

of the animal ${ }^{(60)}$. However, feeding regimens under intensive aquaculture production apparently override the impact of the season on the fatty acid profile of farmed gilthead sea bream $^{(22)}$. This notion is supported by data from the present study, and the MPCA analysis revealed that the $68 \%$ of the total variation in the muscle fatty acid profile of TL is explained by the dietary component. Likewise, alterations in the muscle fatty acid profile of cultured Chinook salmon are viewed as a direct consequence of changes in body weight, fat deposition and ration size ${ }^{(61)}$. This information is of relevance and highlights important nutritional and quality traits, in particular for meeting human requirements for $n-3$ PUFA and HUFA, which needs to be considered for a proper timing and use of FO finishing diets for the recovery of a marine fatty acid profile in fish fed vegetable oils through most of the production cycle c $^{(29,30,39)}$.

The degree of unsaturation of fatty acids mediates the fluidity and structural integrity of cell membranes, which may exacerbate signs of EFA deficiency during fish overwintering $^{(1,62,63)}$. This is the reason why the analysis of PL fatty 
acid profiles was focused in the present study on the cold season. At this time, the factor score plot showed two major clusters corresponding to PL and TL subgroups. In addition, the PL branch of fish fed the control, $33 \mathrm{VO}$ and $66 \mathrm{VO}$ diets appeared as a high homogeneous group, which evidenced the robustness of the PL fatty acid profile when EFA requirements were theoretically covered. However, fish fed the VO diet were deficient in EFA, and PL-VO appeared as an outlier group in the MPCA analysis. More detailed analyses revealed the relative enrichment of these fish in $20: 2 n-6,20: 3 n-6$ and $20: 3 n-3$. Since vegetable oils are devoid of these fatty acids and they are part of the biosynthetic routes of $n-6$ and $n-3$ HUFA, this finding highlights adaptive attempts to alleviate EFA deficiencies. The accumulation of $20: 3 n-6$ indicates increased $\Delta-6$ desaturation and elongation of dietary $18: 2 n-6$ that is driven by increased dietary and tissue levels of this fatty acid, derived from vegetable oils, as well as reduced tissue levels of $n-3$ HUFA $^{(8)}$. The increased levels of $20: 2 n-6$ and $20: 3 n-3$, which are 'dead-end' elongation products of $18: 2 n-6$ and $18: 3 n-3$, respectively, reflect increased levels of dietary $\mathrm{C}_{18}$ PUFA although increased levels of $20: 3 n-9$, a marker of EFA deficiency, were not observed. In gilthead sea bream, the expression of $\Delta-6$ desaturase is highly induced in fish fed a HUFA-free diet ${ }^{(10)}$. There is also now evidence for a regulatory role of conjugated linoleic acid upon the hepatic and intestine expression of fatty acyl elongase and $\Delta-6$ fatty acyl desaturase ${ }^{(64)}$. However, a low activity of $\Delta-5$ fatty acyl desaturase activity has been reported either in vitro ${ }^{(65)}$ or in vivo ${ }^{(9)}$, which may act as a major constraining factor for bioconversion of $\mathrm{C}_{18}$ PUFA into $\mathrm{C}_{20}$ and $\mathrm{C}_{22}$ HUFA at appreciable rates.

In summary, data on growth performance, tissue histology and fatty acid analysis prompted us to use practical diets with a low inclusion of marine raw materials through most of the production cycle of gilthead sea bream, linking the robustness of the PL fatty acid profile with endocrine, metabolic and somatotropic factors. Precise effects at different developmental stages need to be further evaluated, and, interestingly, muscle fatty acid profiles and MPCA emerge not only as powerful tools to understand foraging ecology and food webs, but also to evaluate alternative and sustainable aquafeeds in a global change scenario.

\section{Acknowledgements}

This research was funded by the European Union (FOOD-CT2006-16249: Sustainable Aquafeeds to Maximise the Health Benefits of Farmed Fish for Consumers, AQUAMAX) and Spanish (AGL2004-06319-CO2) projects. The authors declare that there are no conflicts of interest perceived to bias the study. J. G. B. and S. K. have contributed to the experimental design of the diets. A. S.-B. carried out the histology part of the study. J.-C. N. and L. B.-P. performed the fatty acid analyses and data process, and J. P.-S. coordinated the work.

\section{References}

1. Sargent JR \& Tacon AGJ (1999) Development of farmed fish: a nutritionally necessary alternative to meat. Proc Nutr Soc 58, $377-383$.
2. Watanabe $\mathrm{T}$ (2002) Strategies for further development of aquatic feeds. Fish Sci 68, 242-252.

3. Bell JG, McGhee F, Campbell PJ \& Sargent JR (2003) Rapeseed oil as an alternative to marine fish oil in diets of post-smolt Atlantic salmon (Salmo salar): changes in flesh fatty acid composition and effectiveness of subsequent fish oil "wash out". Aquaculture 218, 515-528.

4. Bransden MP, Carter CG \& Nichols PD (2003) Replacement of fish oil with sunflower oil in feeds for Atlantic salmon (Salmo salar L.): effect on growth performance, tissue fatty acid composition and disease resistance. Comp Biochem Physiol 135B, 611-625.

5. Torstensen BE, Froyland L, Ørnsrud R \& Lie Ø (2004) Tailoring of a cardioprotective muscle fatty acid composition of Atlantic salmon (Salmo salar) fed vegetable oils. Food Chem 87, $567-580$.

6. Watanabe T (1982) Lipid nutrition in fish. Comp Biochem Physiol 73B, 3-15.

7. Sargent JR, Tocher DR \& Bell JG (2002) The lipids. In Fish Nutrition, 3rd ed. pp. 181-257 [JE Halver and RW Hardy, editors]. San Diego, CA: Academic Press.

8. Mourente G, Dick JR, Bell JG \& Tocher DR (2005) Effect of partial substitution of dietary fish oil by vegetable oils on desaturation and (-oxidation of $\left[1-{ }^{14} \mathrm{C}\right] 18: 3 n-3$ (LNA) and $\left[1-{ }^{14} \mathrm{C}\right] 20: 5 n-3$ (EPA) in hepatocytes and enterocytes of European sea bass (Dicentrarchus labrax L.). Aquaculture 248, 173-186.

9. Mourente G \& Tocher DR (1994) In vivo metabolism of $\left[1-{ }^{14} \mathrm{C}\right]$ linolenic acid $(18: 3(n-3))$ and $\left[1-{ }^{14} \mathrm{C}\right]$ eicosapentaenoic acid $(20: 5(n-3))$ in a marine fish: time-course of the desaturation/elongation pathway. Biochim Biophys Acta 1212, 109-118.

10. Seiliez I, Panserat S, Corraze G, Kaushik S \& Bergot P (2003) Cloning and nutritional regulation of a $\Delta 6$-desaturase-like enzyme in the marine teleost gilthead seabream (Sparus aurata). Comp Biochem Physiol B Biochem Mol Biol 135B, 449-460.

11. Sargent J, McEvoy L, Estevez A, Bell G, Bell M, Henderson J \& Tocher D (1999) Lipid nutrition of marine fish during early development: current status and future directions. Aquaculture 179, 217-229.

12. Fontagné S, Geurden I, Escaffre AM \& Bergot P (1998) Histological changes induced by dietary phospholipids in intestine and liver of common carp (Cyprinus carpio L.) larvae. Aquaculture 161, 213-223.

13. Olsen RE, Myklebust R, Kaino T \& Ringo E (1999) Lipid digestibility and ultrastructural changes in the enterocytes of Arctic char (Salvelinus alpinus L.) fed linseed oil and soybean lecithin. Fish Physiol Biochem 21, 35-44.

14. Olsen RE, Dragnes BT, Myklebust R \& Ringo E (2003) Effect of soybean oil and soybean lecithin on intestinal lipid composition and lipid droplet accumulation of rainbow trout, Oncorhynchus mykiss Walbaum. Fish Physiol Biochem 29, 181-192.

15. Caballero MJ, Izquierdo MS, Kjørsvik E, Montero D, Socorro J, Fernández AJ \& Rosenlund G (2003) Morphological aspects of intestinal cells from gilthead seabream (Sparus aurata) fed diets containing different lipid sources. Aquaculture 225, 325-340.

16. Abeywardena MY \& Head RJ (2001) Longchain $n-3$ polyunsaturated fatty acids and blood vessel function. Cardiovasc Res 52, 361-371.

17. Calder PC (2006) Polyunsaturated fatty acids and inflammation. Prostaglandins Leukot Essent Fatty Acids 75, 197-202.

18. Fonseca-Madrigal J, Karalazos V, Campbell PJ, Bell JG \& Tocher DR (2005) Influence of dietary palm oil on growth, tissue fatty acid compositions, and fatty acid metabolism in liver and intestine in rainbow trout (Oncorhynchus mykiss). Aquacult Nutr 11, 241-250. 
19. Fonseca-Madrigal J, Bell JG \& Tocher DR (2006) Nutritional and environmental regulation of the synthesis of highly unsaturated fatty acids and of fatty-acid oxidation in Atlantic salmon (Salmo salar L.) enterocytes and hepatocytes. Fish Physiol Biochem 32, 317-328.

20. Almansa E, Martín MV, Cejas JR, Badía P, Jerez S \& Lorenzo A (2001) Lipid and fatty acid composition of female gilthead seabream during their reproductive cycle: effects of a diet lacking $n$-3 HUFA. J Fish Biol 59, 267-286.

21. Özyurt G, Polat A \& Özkütük S (2005) Seasonal changes in the fatty acids of gilthead sea bream (Sparus aurata) and white sea bream (Diplodus sargus) captured in Iskenderun Bay, eastern Mediterranean coast of Turkey. Eur Food Res Technol 220, $120-124$

22. Grigorakis K (2007) Compositional and organoleptic quality of farmed and wild gilthead sea bream (Sparus aurata) and sea bass (Dicentrarchus labrax) and factors affecting it: a review. Aquaculture 272, 55-75.

23. Izquierdo MS, Obach A, Arantzamendi L, Montero D, Robaina L \& Rosenlund G (2003) Dietary lipid sources for seabream and seabass: growth performance, tissue composition and flesh quality. Aquacult Nutr 9, 397-407.

24. Izquierdo MS, Montero D, Robaina L, Caballero MJ, Rosenlund G \& Ginés R (2005) Alterations in fillet fatty acid profile and flesh quality in gilthead seabream (Sparus aurata) fed vegetable oils for a long term period. Recovery of fatty acid profiles by fish oil feeding. Aquaculture 250, 431-444.

25. Gómez-Requeni P, Mingarro M, Calduch-Giner JA, Médale F, Martin SAM, Houlihan DF, Kaushik S \& Pérez-Sánchez J (2004) Protein growth performance, amino acid utilisation and somatotropic axis responsiveness to fish meal replacement by plant protein sources in gilthead sea bream (Sparus aurata). Aquaculture 232, 493-510.

26. De Francesco M, Parisi G, Pérez-Sánchez J, Gómez-Requeni P, Médale F, Kaushik SJ, Mecatti M \& Poli BM (2007) Effect of high level fish meal replacement by plant proteins in gilthead sea bream (Sparus aurata) on growth and body/fillets quality traits. Aquacult Nutr 13, 361-372.

27. Benedito-Palos L, Saera-Vila A, Calduch-Giner JA, Kaushik S \& Pérez-Sánchez J (2007) Combined replacement of fish meal and oil in practical diets for fast growing juveniles of gilthead sea bream (Sparus aurata L.): networking of systemic and local components of GH/IGF axis. Aquaculture 267, 199-212.

28. Kelley DE (2002) Skeletal muscle triglycerides - an aspect of regional adiposity and insulin resistance. Ann NY Acad Sci 967, 135-145.

29. Torstensen BE, Froyland L, Ørnsrud R \& Lie Ø (2005) Tailoring of Atlantic salmon (Salmo salar L.) flesh lipid composition and sensory quality by replacing fish oil with a vegetable oil blend. J Agric Food Chem 53, 10166-10178.

30. Mourente G, Good JE, Thompson KD \& Bell JG (2007) Effects of partial substitution of dietary fish oil with blends of vegetable oils, on blood leukocyte fatty acid compositions, inmune function and histology in European sea bass (Dicentrarchus labrax L.). Br J Nutr 98, 770-779.

31. Folch J, Lees N \& Sloane Stanley GH (1957) A simple method for isolation and purification of total lipides from animal tissues. J Biol Chem 226, 497-509.

32. Christie WW (1982) Lipid Analysis. Isolation, Separation, Identification and Structural Analysis of Lipids, 2nd ed., p. 207 [WW Christie, editor]. Oxford: Pergamon Press.

33. Le Milinaire C, Gatesoupe FJ \& Stephan G (1983) Quantitative approach to $n-3$ long-chain poly-unsaturated fatty-acid requirement of turbot (Scophthalmus maximus) larvae (article in French). C R Seances Acad Sci III 296, 917-920.

34. Gatesoupe FJ, Leger C, Boudon M, Metailler R \& Luquet P (1977) Lipid feeding of turbot (Scophthalmus maximus L.).
Influence on growth of supplementation with methyl esters of linolenic acid and fatty acids of $\omega 9$ series. Ann Hydrobiol 8, $247-254$

35. Lee SM, Lee JH \& Kim KD (2003) Effect of dietary essential fatty acids on growth, body composition and blood chemistry of juvenile starry flounder (Platichthys stellatus). Aquaculture 225, 269-281.

36. Leger C, Gatesoupe FJ, Metailler R, Luquet P \& Fremont L (1979) Effect of dietary fatty acids differing by chain lengths and $\omega$ series on the growth and lipid composition of turbot Scophthalmus maximus L. Comp Biochem Physiol 64B, 345-350.

37. Skalli A \& Robin JH (2004) Requirement of $n$-3 long chain polyunsaturated fatty acids for European sea bass (Dicentrarchus labrax) juveniles: growth and fatty acid composition. Aquaculture 240, 399-415.

38. Kalogeropoulos N, Alexis MN \& Henderson RJ (1992) Effects of dietary soybean and cod-liver oil levels on growth and body composition of gilthead bream (Sparus aurata). Aquaculture 104, 293-308.

39. Regost C, Arzel J, Robin J, Rosenlund G \& Kaushik SJ (2003) Total replacement of fish oil by soybean or linseed oil with a return to fish oil in turbot (Psetta maxima): 1. Growth performance, flesh fatty acid profile, and lipid metabolism. Aquaculture 217, 465-482.

40. Piedecausa MA, Mazon MJ, Garcia Garcia B \& Hernandez MD (2007) Effects of total replacement of fish oil by vegetable oils in the diets of sharpsnout seabream (Diplodus puntazzo). Aquaculture 263, 211-219.

41. Mingarro M, Vega-Rubín de Celis S, Astola A, Pendón C, Martínez Valdivia M \& Pérez-Sánchez J (2002) Endocrine mediators of seasonal growth in gilthead sea bream (Sparus aurata): the growth hormone and somatolactin paradigm. Gen Comp Endocrinol 128, 102-111.

42. Gómez-Requeni P, Mingarro M, Kirchner S, et al. (2003) Effects of dietary amino acid profile on growth performance, key metabolic enzymes and somatotropic axis responsiveness of gilthead sea bream (Sparus aurata). Aquaculture 220, $749-767$

43. Sitjà-Bobadilla A, Peña-Llopis S, Gómez-Requeni P, Médale F, Kaushik S \& Pérez-Sánchez J (2005) Effect of fish meal replacement by plant protein sources on non-specific defence mechanisms and oxidative stress in gilthead sea bream (Sparus aurata). Aquaculture 249, 387-400.

44. Salhi M, Hernández-Cruz CM, Bessonart M, Izquierdo MS \& Fernández-Palacios H (1999) Effect of different dietary polar lipid levels and different $n$-3 HUFA content in polar lipids on gut and liver histological structure of gilthead seabream (Sparus aurata) larvae. Aquaculture 179, 253-263.

45. Liu J, Caballero MJ, Izquierdo MS, El-Sayed Ali T, HernándezCruz CM, Valencia A \& Fernández-Palacios H (2002) Necessity of dietary lecithin and eicosapentaenoic acid for growth, survival, stress resistance and lipoprotein formation in gilthead sea bream Sparus aurata. Fish Sci 68, 1165-1172.

46. Browning JD \& Horton JD (2004) Molecular mediators of hepatic steatosis and liver injury. $J$ Clin Invest 114, 147-152.

47. Avramoglu RK, Basciano H \& Adeli K (2006) Lipid and lipoprotein dysregulation in insulin resistant states. Clin Chim Acta 368, 1-19.

48. Sitjà-Bobadilla A, Mingarro M, Pujalte MJ, Garay E, AlvarezPellitero P \& Pérez-Sánchez J (2003) Immunological and pathological status of gilthead sea bream (Sparus aurata L.) under different long-term feeding regimes. Aquaculture 220, 707-724.

49. Caballero MJ, Izquierdo MS, Kjørsvik E, Fernández AJ \& Rosenlund G (2004) Histological alterations in the liver of sea bream, Sparus aurata L., caused by short- or long-term feeding 
with vegetable oils. Recovery of normal morphology after feeding fish oil as the sole lipid source. J Fish Dis 27, 531-541.

50. Wassef EA, Wahby OM \& Sakr EM (2004) Effect of dietary vegetable oils on health and liver histology of gilthead seabream (Sparus aurata) growers. Aquac Res 38, 852-861.

51. Saera-Vila A, Calduch-Giner JA, Gómez-Requeni P, Médale F, Kaushik S \& Pérez-Sánchez J (2005) Molecular characterization of gilthead sea bream (Sparus aurata) lipoprotein lipase. Transcriptional regulation by season and nutritional condition in skeletal muscle and fat storage tissues. Comp Biochem Physiol 142B, 224-232.

52. Saera-Vila A, Calduch-Giner JA, Navarro I \& Pérez-Sánchez J (2007) Tumour necrosis factor (TNF) $\alpha$ as a regulator of fat tissue mass in the Mediterranean gilthead sea bream (Sparus aurata L.). Comp Biochem Physiol 146B, 338-345.

53. Canty DJ \& Zeisel SH (1994) Lecithin and choline in human health and disease. Nutr Rev 52, 327-339.

54. Patova OM, Prozorovskaia NN, Torkhovskaia TI, Baranova VS \& Guseva DA (2004) Biological effects of the soybean phospholipids. Biomed Khim 50, 436-450.

55. Bell JG, McEvoy J, Tocher DR, McGhee F, Campbell PJ \& Sargent JR (2001) Replacement of fish oil with rapeseed oil in diets of Atlantic salmon (Salmo salar) affects tissue lipid compositions and hepatocyte fatty acid metabolism. J Nutr 131, 1535-1543.

56. Moya-Falcon C, Hvattum E, Tran TN, Thomassen MS, Skorve J \& Ruyter B (2006) Phospholipid molecular species, (-oxidation, desaturation and elongation of fatty acids in Atlantic salmon hepatocytes: effects of temperature and 3-thia fatty acids. Comp Biochem Physiol 145B, 68-80.

57. Caballero MJ, Obach A, Rosenlund G, Montero D, Gisvold M \& Izquierdo MS (2002) Impact of different dietary lipid sources on growth, lipid digestibility, tissue fatty acid composition and histology of rainbow trout, Oncorhynchus mykiss. Aquaculture 214, 253-271.
58. Richard N, Mourente G, Kaushik S \& Corraze G (2006) Replacement of a large portion of fish oil by vegetable oils does not affect lipogenesis, lipid transport and tissue lipid uptake in European seabass (Dicentrarchus labrax L.). Aquaculture 261, $1077-1087$.

59. Mourente G \& Bell JG (2006) Partial replacement of dietary fish oil with blends of vegetable oils (rapeseed, linseed and palm oils) in diets for European sea bass (Dicentrarchus labrax L.) over a long term growth study: effects on muscle and liver fatty acid composition and effectiveness of a fish oil finishing diet. Comp Biochem Physiol 145B, 389-399.

60. Kaushik SJ, Corraze G, Radunz-Neto J, Larroquet L \& Dumas J (2006) Fatty acid profiles of wild brown trout and Atlantic salmon juveniles in the Nivelle basin. J Fish Biol 68, 1376-1387.

61. Kiessling A, Pickova J, Eales JG, Dosanjh B \& Higgs D (2005) Age, ration level, and exercise affect the fatty acid profile of chinook salmon (Oncorhynchus tshawytscha) muscle differently. Aquaculture 243, 345-356.

62. Jobling M \& Bendiksen EA (2003) Dietary lipids and temperature interact to influence tissue fatty acid compositions of Atlantic salmon, Salmo salar L., parr. Aquac Res 34, $1423-1441$.

63. Skalli A, Robin JH, Le Bayon N, Le Delliou H \& Person-Le Ruyet J (2006) Impact of essential fatty acid deficiency and temperature on tissues' fatty acid composition of European sea bass (Dicentrarchus labrax). Aquaculture 255, 223-232.

64. Diez A, Menoyo D, Pérez-Benavente S, et al. (2007) Conjugated linoleic acid affects lipid composition, metabolism, and gene expression in gilthead sea bream (Sparus aurata L.). J Nutr 137, 1363-1369.

65. Tocher DR \& Ghioni C (1999) Fatty acid metabolism in marine fish: low activity of fatty acyl $\Delta 5$ desaturation in gilthead sea bream (Sparus aurata) cells. Lipids 34, 433-440. 